\title{
Corporate Social Responsibility in Times of the COVID-19 Pandemic
}

\begin{abstract}
Summary
The COVID-19 pandemic has caused various disruptions in the production chains of Multinational Enterprises (MNEs). Along with other disruptions there has been a drop in product sales, often due to lockdown measures, which have resulted in last-minute order cancellations, non-payment of already-purchased resources and already-made products, and hence terminations of employment contracts. International organizations and nongovernmental organizations have called upon MNEs to act in line with the principles of corporate social responsibility (CSR) and honor the contracts. The aim of this article is to analyze to what extent this moral appeal is also a (quasi-)legal appeal following from international norms on CSR. After an assessment of the main labor law problems caused by the COVID-19 pandemic, an analysis follows on each of the identified problems. The conclusion of the analysis is that MNEs indeed responsible, not only morally, but also in terms of these (quasi-)legal international CSR norms. Keywords: CSR, COVID-19, UN Guiding Principles, global production chains, MNEs, ILO, Responsible Business Conduct, RBC.
\end{abstract}

\section{Introduction}

In times of the COVID-19 pandemic corporate social responsibility (CSR) is even more important than in normal times. ${ }^{1}$ However, although there are strong moral appeals on MNEs (Multinational Enterprises) to take their responsibility, the question is whether MNEs

* Visiting professor and Head of the Centre for International and European Labour Law Studies at the University of Warsaw, and Assistant Professor and Academic Coordinator of the Advanced Master Global and European Labour Law at Leiden University.

${ }^{1}$ In this introduction I try to substantiate the importance of CSR with as many references as I could and is sensible. However, developments are extremely fast, which makes it impossible to keep up with all of them. Most of all, this indicates how topical the issue is at the moment of writing this article. 
are also required to act responsibly by (quasi-)legal instruments? More particularly these instruments are: the ILO's Tripartite Declaration of Principles concerning Multinational Enterprises and Social Policy (further: MNE Declaration), the OECD's Guidelines for Multinational Enterprises (further: OECD Guidelines), and the UN Guiding Principles on business and human rights (further: UN GPs) including the Ruggie framework protect, respect and remedy.

Before addressing the above question more elaborately, we need to take one step back and review what is happening in these times of the COVID-19 pandemic. Discussions about MNEs and their supply chains started when parts of China went into lockdown and concerns were raised that some products might become scarce ${ }^{2}$ because ever since the 1980s companies in Europe, the United States of America (US) and Australia have massively outsourced their production processes to China and other Asian countries. ${ }^{3}$ When COVID-19 was declared a global pandemic, and Europe, Australia and the US went into lockdown in March $2020^{4}$ another effect of the outsourcing practices of companies became strongly visible. Due to the lockdowns, consumption levels decreased in unprecedented numbers, ${ }^{5}$ which

${ }^{2}$ For example, E. White, S. Jung-a, J. Miller and P. Cambell, EU and US carmakers warn 'weeks away' from China parts shortage, 'Financial Times' 4 February 2020; M. Davey, From batteries to shutters: Australian firms eye potential coronavirus shortages, 'The Guardian' 21 February 2020; A. Cheng, PEG Says 17,600 Products Could Be Affected By Coronavirus In China, Highlighting Supply Chain Risk, 'Forbes' 20 February 2020; J. Christensen, Coronavirus outbreak in China could lead to 'critical' shortages of medical products in the US, 'CNN' 26 February 2020; and D. Ivanov, Predicting the impacts of epidemic outbreaks on global supply chains: A simulation-based analysis on the coronavirus outbreak (COVID-19/ SARS-CoV-2) case, 'Transportation Research Part E' 136 (March 2020) 101922.

${ }^{3}$ See for an overview of the development of outsourcing: J. Hätönen and T. Eriksson, 30+ years of research and practice of outsourcing-Exploring the past and anticipating the future, 'Journal of International Management' 15 (2009) 142-155.

${ }^{4}$ See for an overview of exact dates and forms of lockdown for approximately sixty countries, the country reports in the special issue of the 'Italian Labour Law e-Journal' on COVID-19 and Labour Law. A Global Review, (edited by B.P. ter Haar, E. Menegatti, I. Senatory, and E. Sychenko), available at: https://illej.unibo.it/ (accessed 21 May 2020).

${ }^{5}$ Cf. N. Neuteboom and P. Golec, Consumers in the coronavirus era, 'ABN AMRO' 21 April 2020 (statistics for the Netherlands); and Belapatiño c.s., The COVID-19 impact on Consumption in Real Time and High Definition, 'BBVA Research' 24 April 2020 (with data for Spain, Turkey, Mexico, the USA, Colombia, Argentina and Peru). 
has put many companies at the brink of bankruptcy had they not received government support. ${ }^{6}$ The instant drop in sales resulted in a prompt termination of contracts, even in cases when some stages of the production process had already been completed, e.g. fabrics had already been bought and cut, and the cancellation or deferral of planned (future) orders. ${ }^{7}$ A third challenge of the COVID-19 pandemic for global value chains is the (further) outbreak of the virus in the "sourcing" countries, particularly countries in South-East Asia, Latin America, and Africa, ${ }^{8}$ which will result in lower production levels in the plants that are not affected by the lockdowns in Europe, Australia, and the US. ${ }^{9}$ Although not very visible yet at the time of writing this article,$^{10}$ it is only logical when we follow the first signals that due to

${ }^{6}$ See for an overview of the different types of government measures the country reports in the special issue of the Italian Labour Law e-Journal on COVID-19 and Labour Law. A Global Review (op cit.).

7 Among many others: A. Hossain, Coronavirus: Two million Bangladesh jobs 'at risk' as clothes orders dry up, 'BBC Bengali' 29 April 2020; A. Seric, H. Görg, S. Mösle and M. Windisch, Managing COVID-19: How the pandemic disrupts global value chains, 'Opinion on UNIDO's Industrial Analytics Platform' April 2020 (with specific attention for China); S. Meenakshi, Covid-19: It's time to show what responsible means, 'Fair wear Foundation (Stories)', 28 April 2020, available at: www.fairwear.org/stories/covid -19-its-time-to-show-what-responsible-means (accessed 21 May 2020); and Clean Clothes Campaign, COVID-19 Demands in defence of Garment Workers in Global Supply Chains, 18 May 2020, available at: cleanclothes.org/news/2020/covid-19-short-termdemands-in-defense-of-garment-workers-in-global-supply-chains (accessed 21 May 2020).

${ }^{8}$ In many of these countries forms of lockdowns took place late March/early April 2020. See: https://gisanddata.maps.arcgis.com/apps/dashboards/bda7594740fd40299423467b48e9ecf6 (accessed 21 May 2020).

${ }^{9}$ In general industries actually thriving well during COVID-19 include online (home) entertainment (e.g. Netflix, but also Nintendo, etc.), online shops like Amazon, online meeting platforms (e.g. Citrix, but also programmes such as MS Teams, Google meet, Zoom, etc.), companies producing (hand)sanitizers, and the pharmacy. Cf. J. Barro, The Companies That Stand to Profit from the Pandemic, 'New York Intelligencer' 14 April 2020; and J. Valinsky, Business is booming for these 14 companies during the coronavirus pandemic, 'CNN Business' 7 May 2020.

${ }_{10}$ The NGO Clean Clothes Campaign is keeping track of the effects in the garment industry with daily updates in what they call a "live blog": https://cleanclothes.org/ news/2020/live-blog-on-how-the-coronavirus-influences-workers-in-supply-chains (accessed 30 June 2020). See for a theoretical assessment of the pandemic's impact on supply chains: D. Ivanov and A. Das, Coronavirus (COVID-19/SARS-CoV-2) and supply chain resilience: a research note, 'International Journal Integrated Supply Management' 13(1) 2020, 90-102. 
lockdowns production in Europe has dropped and caused delivery problems within Europe as well as in China. ${ }^{11}$

What the COVID-19 pandemic makes conspicuous is that the economy and therewith the world of work is highly globalised, the ramification of which are multipleinterdependencies. Of course, this in itself is not news. Debates about the pros and cons of the globalised economy are already ongoing for a few decades. ${ }^{12}$ What is worth indicating, however, is that the COVID-19 pandemic rather painfully revealed how far the globalisation has gotten and how much we have become dependent on one another. This was made most visible by shortages in personal protective equipment (PPE) for workers in the healthcare sector. ${ }^{13}$ In response to this, some governments, such as the Donald Trump administration in the US ${ }^{14}$ or the authorities in France ${ }^{15}$ have

11 V. Hoeks, Corona onder controle? De Chinezen willen door! Hoe China werkt volgens 'het nieuwe normaal' en hoe Europa daarop in kan springen, available at: leidenasiacentre.nl/ corona-onder-controle-de-chinezen-willen-door-dutch/ (accessed 23 May 2020).

${ }^{12}$ In the field of labour law, among many other contributions: J.D.R. Craig and S. M. Lynk, Globalization and the future of labour law, Cambridge, CUP, 2006; B. Hepple, Labour Laws and Global Trade Oxford, Hart Publishing, 2005; and J. Conaghan, R.M. Fischl and K. Klare (eds.), Labour Law in an Era of Globalization. Transformative Practices E Possibilities Oxford, OUP, 2002.

${ }^{13}$ Cf. Oxford Business Group, The impact of Covid-19 on global supply chains, 'COVID 19 Economic Impact Assessment’ 24 April 2020; M. L. Ranney, V. Griffeth, and A. K. Jha, Critical Supply Shortages - The Need for Ventilators and Personal Protective Equipment during the Covid-19 Pandemic, 'The New England Journal of Medicine' 30 April 2020; 382:e41; Asian Development Bank, Global Shortage of Personal Protective Equipment amid COVID-19: Supply Chains, Bottlenecks, and Policy Implications, 'ADB Briefs' 130, April 2020; and United Nations, UN leads bid to help 135 countries get vital COVID-19 medical kit, amid severe global shortages 28 April 2020. Within the European Union the export of PPE got restricted by an 'export authorisation' by COMMISSION IMPLEMENTING REGULATION (EU) 2020/402 of 14 March 2020 making the exportation of certain products subject to the production of an export authorisation, (OJ [2020] LI77/1).

${ }^{14}$ Rethinking outsourcing practices were already high on the agenda of the Trump government, steps to reduce dependence on China seem to find firmer ground, e.g. H. Pamuk and A. Shahal, Trump administration pushing to rip global supply chains from China: officials, 'Reuters (Business)' 4 May 2020.

${ }_{15}$ Minister Bruno Le Maire's speech European industrial independence of 2 April 2020, available at: www.gouvernement.fr/en/european-industrial-independence (accessed on 23 May 2020). A similar call for reshoring of production and services was made in the Netherlands by the Christen Democratic party (CDA), albeit that their first call for reshoring, made at local level, dates back to 2013 and currently is put in the context of the question whether the Netherlands has become too dependent on China: D. Heeringa, Gaan we in plaats van 'Made in China' vaker 'Made in the Netherlands' zien?, 'Nieuwsuur 
called to rethinking of outsourcing practices in order to assure, in the words of the French minister of economic affairs, "sovereign" and "independent" supplies. ${ }^{16}$ Although this is an interesting issue that will affect the world of work, it is a political rather than a legal problem. Yet, an issue that is much less discussed at the political level, despite being of no less importance, is the question about the responsibility of MNEs for their workers throughout their global supply chains in these times of the COVID-19 pandemic. ${ }^{17}$ This is not only a political, but also a legal question when addressed in the context of corporate social responsibility (CSR), with the above mentioned international instruments recognising that MNEs should avoid causing or contributing to adverse impacts ${ }^{18}$ or seek to prevent or mitigate an adverse impact when such can directly be linked to their operations, products or services via a business relationship. ${ }^{19}$

In the context of the COVID-19 pandemic there is a call for MNEs to take their responsibility. But, one may ask, what is their responsibility exactly? This very question will be addressed in the present article. Thereto, the following section presents the analysis of what kind of responsibility MNEs are called upon at the moment. Section 3, in turn, continues with an analysis of the labour rights issues MNEs are expected to respect based on the three leading international public CSR initiatives. In other words: the analysis will be made of what exactly is called for and what is required. The article concludes in section 4 with a clear indication to what extend we can expect the responsible business conduct (hereafter: RBC) that MNEs are called for based on the three leading international (public) CSR initiatives.

For completeness sake it is noticed here that the focus of this article lies with the production industry, hence leaving out the service industry. The service industry is faced with different challenges that seem to

(TV programme)' 29 May 2020; and A. Koç, Volledige Steun van de raad voor het terughalen van productie uit lagelonenlanden, 'Nieuwsbrief CDA Enschede', 15 November 2013.

${ }^{16}$ Minister Bruno Le Maire's speech European industrial independence (op cit.); and more general A. Seric, H. Görg, S. Mösle, and M. Windisch, Managing COVID-19: How the pandemic disrupts global value chains, 'World Economic Forum' 27 April 2020.

17 See references above in footnote 6 .

${ }_{18}$ Par. 10 of section II General Policies of the OECD Guidelines for MNEs.

19 Par. 11 of section II General Policies of the OECD Guidelines for MNEs. 
have a less disruptive impact on the world of work. ${ }^{20}$ Moreover, many of them are actually thriving rather well because of the COVID-19 pandemic, for example those offering internet communication platforms, such as: Zoom, Google Meet, Skype, etc. ${ }^{21}$ That the production industry is more affected than the service industry can also be deduced from the outcome of the survey conducted by the employers organisation of the ILO on the issue of productivity: no business member in Europe has dropped its production capacity by 75 per cent or more, while more than half of them are still working at their full capacity, whereas 14 per cent of the business members in Africa operates below 25 per cent of its capacity and about one third of them operates below half of their normal capacity. ${ }^{22}$

\section{MNEs' responsibilities as called for during the COVID-19 pandemic}

Several issues have been addressed in the introduction in order to illustrate what kind of disruptions the COVID-19 pandemic is causing in the supply chains. In this section I will try to translate these problems in terms of MNE responsibilities in the context of CSR or Responsible Business Conduct (RBC).

When talking about the effect of the COVID-19 pandemic on supply chains it can be helpful to sketch a simplified supply chain to get an impression where and when in the supply chain as well as geographical locations disruptions have taken or will take ${ }^{23}$ place. As can

${ }^{20}$ E.g. tele- or remote-working; finding a work-life balance; working time (especially the right not to be connected).

${ }^{21}$ CF. The Financial Times which devoted a special series to companies that prosper during the pandemic: www.ft.com/content/d298bf34-9644-4b49-be09-c775256639ba (accessed 25 July 2020).

${ }_{22}$ IOE and ILO-ACT/EMP, A global survey of employer and business membership organizations: Inside impacts and responses to COVID-19, published by the International Labour Office 29 June 2020, pp. IX-X and p. 19.

${ }^{23}$ Although the COVID-19 pandemic has had direct effects, many predictions are being made that an economic crisis will follow of which the impact is uncertain. On 14 April 2020 Aljazeera, for example, headed an article with IMF says 'worst recession since Great Depression' is likely, including more headings about joblessness in Australia, debt increases in Africa, and in general a rise in the number of people being pushed into poverty reported by Oxfam (available at: www.aljazeera.com/ajimpact/imf-worstrecession-great-depression-200414125253286.html (accessed 30 June 2020). The OECD's 
be seen in Figure 1, the simplified supply chain exists of five parts raw materials - half products - assembly - distribution - sales markets. To make it more concrete we can use as an illustration the production chain of a T-shirt. ${ }^{24}$ The raw material for a T-shirt is cotton, ${ }^{25}$ half products are yarn and fabrics, ${ }^{26}$ assembly of a T-shirt takes place in sowing factories; ${ }^{27}$ the T-shirts are then transported ${ }^{28}$ from the production place to the sales markets, which are often located in Europe, the US, Canada, and Australia. In the footnotes I have indicated the main "production" countries for each of these steps. This is helpful for another element in Figure 1 namely, to make visible when and where the different parts of the production chains are disrupted. This is relevant, because the COVID-19 pandemic developed (and still does) differently in different regions of the world, ${ }^{29}$ consequently, MNEs' production chains are disrupted at various parts of the chain and moments in time. Understanding this is relevant because it is of influence on the expectations in terms of Responsible Business Conduct (RBC) in these times of the COVID-19 pandemic.

economic outlook shows that the COVID-19 pandemic 'has triggered the most severe recession in nearly a century' and that the path to recovery remains uncertain but in any case the effects of the pandemic will be long lasting (see at: www.oecd.org/economicoutlook/june-2020/ (accessed 30 June 2020)).

${ }^{24}$ Of course, also for a T-shirt this is a simplified process. For instance, it does not include all kinds of processes a piece of cloth can undergo, like colouring and emblazoning, etc. However, for the purpose of this article this simplified process suffices.

${ }^{25}$ Top ten cotton-producing countries are: China, India, the US, Pakistan, Brazil, Uzbekistan, Turkey, Australia, Turkmenistan, and Mexico. Source: www.worldatlas. com/articles/top-cotton-producing-countries-in-the-world.html (accessed 23 July 2020).

${ }^{26}$ Top ten cotton yarn-producing countries are: China, India, the US, Pakistan, Indonesia, Brazil, Turkey, South Korea, Italy, and Egypt. Top then cotton cloth-producing countries are: China, India, Russia, US, Japan, Germany, Hong-Kong, Egypt, France, and Romania. Source for both: www.yourarticlelibrary.com/industries/leading-produ cers-of-cotton-yarn-in-the-world/25406 (accessed 23 July 2020).

27 Top ten textile-exporting countries: China, Germany, Bangladesh, Vietnam, India, Italy, Turkey, US, Hong-Kong, Spain. Source: www.fibre2fashion.com/industryarticle/8471/top-10-exporting-countries-of-textile-and-apparel-industry (accessed 23 July 2020).

${ }^{28}$ Of course, there are more staged involving transportation in the production chain itself, but this is one of the most visible ones.

${ }^{29}$ This is roughly deduced from the statistical data gathered at: https://gisanddata.maps.arcgis.com/apps/dashboards/bda7594740fd40299423467b48e9ecf6 (accessed 23 July 2020). 
Table 1. Simplified production chain with disruption indications in time and per region

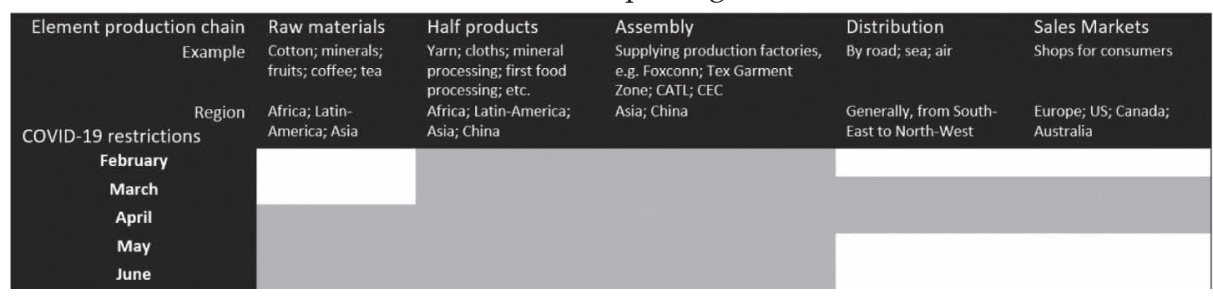

The grey areas in Table 1 represent the ruptures ${ }^{30}$ in parts of the simplified production chain caused by the outbreak of COVID-19 and governmental measures following the outbreak to contain the virus as much as possible. It clearly shows that the disruptions occur in different moments in time. Consequently, different problematic situations in the production chain have arisen.

The first rupture in supply chains is caused by the outbreak of COVID-19 in China which was followed by lockdowns that affected the productivity of Chinese companies, including those part of the supply chains of (Western) MNEs. As indicated in the introduction, this resulted, among others, in shortages of parts of products that are assembled in Europe. It also caused shortages of products, especially for those which demand grew exponentially, such as the personal protection equipment for those working in the healthcare sector. The second rupture is caused by an abrupt drop in demand of goods due to lockdowns in the countries where most of the products are being sold. As indicated in the introduction, this resulted in instant cancellations of already placed orders and an extreme drop in the number of new orders. The third rupture is caused by the outbreak of COVID-19 in regions where most of the production and resourcing countries are located. Thus, apart from China, Asian countries like Bangladesh, Vietnam, and India, as well as Latin-American and African countries. Moreover, in this same period of time European countries, Australia, and Canada started to relax the lock down measures (most of them since May/June 2020), ${ }^{31}$ which meant restarting their economies resulting in an increase in the demand of (parts of) goods produced in those

${ }^{30}$ Cf. D. Ivanov and A. Das, op cit.

${ }^{31}$ Given the fact that the response to COVID-19 in the US is vastly different from the other typical "sales market countries," I leave this country out of consideration. 
countries just hit by the COVID-19 pandemic making the disruptive effect of the pandemic even more apparent. ${ }^{32}$ Besides limited production capacity due to governmental lockdown measures, productivity also decreased since more and more workers called in sick because they had to quarantine themselves, either because they themselves were infected with the virus or they have been in close contact with someone infected with the virus.

The ruptures caused by the COVID-19 pandemic have a combined health, economic, and social impact..$^{33}$ What is interesting for this article is to identify what problems these ruptures cause with respect to labour rights and which of these causes can be related to the conduct of MNEs. When we map the problems related to where in the production chain the rupture appears (see Table 1), roughly speaking, the following two (broadly formulated) labour law issues keep surfacing: 1) occupational safety and health (OSH), including coping with peak working hours for those who have to work during the times of COVID-19, and PPE; and 2) a reduction in working hours resulting in furloughing or (partial) termination of the employment relationship by the employer. A number of scholars as well as the ILO and the European Union have also mentioned a heightened risk of human trafficking and forced labour, ${ }^{34}$ however, this cannot be deduced from Table 1.

32 This is not much stressed in the news yet (the period of writing this article), but just a matter of time to become noticeable. See for example considerations in this article about the garment industry in India: www.unido.org/stories/indias-manufacturingreels-impact-covid-19 (accessed 25 July 2020).

${ }^{33}$ Cf. IOE and ILO-ACT/EMP, A global survey of employer and business membership organizations: Inside impacts and responses to COVID-19, published by the International Labour Office, 29 June 2020.

${ }^{34}$ For example, J. Hughes, L. Hamzi, and R. Mashru, 'Corporate Human Rights Due Diligence in times of COVID-19', EJIL:Talk! Blog of the European Journal of International Law 30 July 2020. See also: J. Patel and S. Child, 'Rise in forced labour expected amid the Covid-19 economic crisis', MailEGuardian 20 June 2020; ILO, 'COVID-19 impact on child labour and forced labour: The response of the IPEC+ Flagship Programme', available at www.ilo.org/ipec-plus; and EU Agency for Fundamental Rights (FRA), 'Stop labour exploitation and protect workers from COVID-19', News Item 13 July 2020, available at www.fra.europe.eu. 
Table 2. Labour law issues stemming from ruptures in production chains $\mathrm{s}^{35}$

\begin{tabular}{|c|c|c|c|}
\hline $\begin{array}{l}\text { Position in } \\
\text { production } \\
\text { chain causing } \\
\text { the rupture }\end{array}$ & $\begin{array}{l}\text { Relation with } \\
\text { other parts } \\
\text { of the chain }\end{array}$ & $\begin{array}{l}\text { Problems in production } \\
\text { chain }\end{array}$ & Labour law issues \\
\hline Sourcing & $\begin{array}{l}\text { Production } \\
\text { Sales markets }\end{array}$ & $\begin{array}{l}\text { - Shortages in the supply } \\
\text { of raw materials } \\
\text { - Reduction in the number } \\
\text { of goods that can be } \\
\text { produced } \\
\text { - Reduction in supply } \\
\text { of goods } \\
\text { - Shortages of goods }\end{array}$ & $\begin{array}{l}\text { - OSH in sourcing coun- } \\
\text { tries } \\
\text { - Reduction of working } \\
\text { hours } \\
\text { - (partial) termination } \\
\text { of the employment } \\
\text { relationship } \\
\text { - furloughing }\end{array}$ \\
\hline Production & $\begin{array}{l}\text { Sourcing } \\
\text { Sales markets }\end{array}$ & $\begin{array}{l}\text { - Drop in demand for raw } \\
\text { materials } \\
\text { - Reduction in demand of } \\
\text { work } \\
\text { - Shortages of goods }\end{array}$ & $\begin{array}{l}\text { - OSH in production coun- } \\
\text { tries } \\
\text { - Reduction of working } \\
\text { hours } \\
\text { (partial) termination } \\
\text { of the employment } \\
\text { relationship } \\
\text { - Furloughing }\end{array}$ \\
\hline $\begin{array}{l}\text { Sales markets } \\
\text { shops) }\end{array}$ & \begin{tabular}{|l} 
Sourcing \\
Production
\end{tabular} & $\begin{array}{l}\text { - Drop in demand of goods } \\
\text { - Reduction in orders for } \\
\text { production of goods } \\
\text { - Drop in demand for raw } \\
\text { materials }\end{array}$ & $\begin{array}{l}\text { - Reduction of working } \\
\text { hours } \\
\text { - (partial) termination } \\
\text { of the employment } \\
\text { relationship } \\
\text { - Furloughing }\end{array}$ \\
\hline Transport & $\begin{array}{l}\text { Sourcing } \\
\text { Production } \\
\text { Sales Markets }\end{array}$ & $\begin{array}{l}\text { - Boarder closures / longer } \\
\text { waiting lines at the board- } \\
\text { ers } \\
\text { - Limited air transport (many } \\
\text { airplanes are grounded) } \\
\text { - Longer delivery times } \\
\text { - Drop/delay in production of } \\
\text { goods - more peak work } \\
\text { - Shortages of products }\end{array}$ & $\begin{array}{l}\text { - OSH (including working } \\
\text { time) transport workers } \\
\text { - Fluctuations of working } \\
\text { hours } \\
\text { - Peaks (overtime) } \\
\text { - Reduction } \\
\text { - (partial) termination } \\
\text { of the employment } \\
\text { relationship } \\
\text { - Furloughing }\end{array}$ \\
\hline
\end{tabular}

When searching for reasons why global production chains seem particularly vulnerable on these labour rights issues, indications can be found that this is related to the so-called Just in Time (JIT) management model. JIT is a management model developed by Toyota (Japan),

${ }^{35}$ In a similar way see: R. Baldwin and R. Freeman, 'Supply chain contagion waves: Thinking ahead on manufacturing 'contagion and reinfection' from the COVID concussion', VoxEU.org 1 April 2020. Inspiration for this is drawn from: D. Ivanov, op cit., p. 4-5. 
which is based on the idea of production on demand, also known as "make-to-order." JIT refers to a process in which stocks are eradicated and every step in the production chain is tensely coordinated so it can be completed "just in time." ${ }^{36}$ From a business perspective JIT offers many advantages, such as the elimination of waste, and a more streamlined and efficient process flow. ${ }^{37}$ The downside of this lean, pull-based practice is that it results in almost immediate shortages of (certain) products such as the PPE ${ }^{38}$ which for example has hampered the $\mathrm{OSH}$ of healthcare workers who are "fighting in the frontlines against COVID-19." ${ }^{39}$ In fact, research carried out before the COVID-19 pandemic had already pointed out that JIT management is characterised by volatile demand of production causing structural situations of (excessive) overtime and insecurity of employment contracts. ${ }^{40}$ These effects have been amplified during the COVID-19 pandemic, ${ }^{41}$ which has resulted in calls for a more resilient supply chain management system that fits the 21 st century. ${ }^{42}$

${ }^{36}$ F. Pisch, Managing Global Production: Theory and Evidence from Just-in-Time Supply Chains, 'CEP Discussion Paper' No 1689 April 2020, p. 2.

${ }^{37}$ R. Locke, The Promise and Limits of Private Power Cambridge, CUP, 2013, p. 152.

38 See references in footnote 13 .

39 This is a rhetoric that has been used by many presidents/leaders, comparing the COVID-19 pandemic with a war against an invisible enemy. Many measures, such as lockdowns and closing of schools are also only known from war situations, as such some parallels can be drawn.

${ }^{40}$ R. Locke, op cit. See also: SOMO, ECCHR and PAX, Responsible disengagement in the time of corona, Position paper, April 2020, p. 2.

${ }^{41}$ Cf. News posts on www.business-humanrights.org about COVID-19 in the supply chains; Live blog of Clean Clothes Campaign op cit.; ILO news, COVID-19 cruelly highlights inequalities and threatens to deepen them, 30 March 2020, available at www.ilo. org (albeit in general, it is a well-known fact that the most vulnerable workers are found down in the global supply chains, exactly there where governments hardly have the (financial) means to adopt protective measure to cope with the consequences of the COVID-19 pandemic); and OECD, COVID-19 and Global Value Chains: Policy Options to Build More Resilient Production Networks, 'OECD Policy Responses to Coronavirus (COVID-19)', 3 June 2020. Moreover, vulnerability in supply chains based on JIT management was already flagged in research before the COVID-19 pandemic, e.g. following one of the heaviest flooding in the history of Thailand: A. Chongvilaivan, Thailand's 2011 flooding: Its impact on direct exports and global supply chains, 'ARTNeT Working Paper Series', No. 113, 2011.

${ }^{42}$ E.g. J. Sarkis, M.J. Cohen, P. Dewick, P. Schröder, A brave new world: Lessons from the COVID-19 pandemic for transitioning to sustainable supply and production, 'Elsevier Public Health Emergency Collection', 17 April 2020 (doi: 10.1016/j.resconrec.2020.104894). 
Another consequence that can be contributed/Another adverse consequence which may be attributed to the JIT-type management system is that it involves the immediate cancellations of orders and commissions for new goods to be produced resulting in the termination of employment contracts with factory workers. ${ }^{43}$ This has raised calls for MNEs to show engagement and behave as socially-responsible companies, not only because the factories and workers need it, ${ }^{44}$ but also because in the future, "when the economy is restarted again," ${ }^{45}$ these factories (and workers) are much needed as their partners in the production chains. ${ }^{46}$ Furthermore, arguments have been made that nonresponsible business behaviour may reflect badly on MNEs as "investors and consumers will look more favourably to companies that have sought to take an RBC approach to the crisis." 47

What the above analysis tells us, is that in terms of RBC in times of the COVID-19 pandemic MNEs are expected to do the following:

1. Ensure all necessary COVID-19 OSH-measures are taken and followed for those who continue to work.

2. Pay speciall attention to instances of human trafficking and forms of forced labour, since especially migrant workers are in a highly vulnerable position.

3. Stay engaged with the suppliers by

a. complying with or respecting contracts; and

b. preserving jobs and securing incomes as much as possible.

4. Transform the JIT management system into a system based on a less volatile demand that is more resilient and better fits the 21st century.

${ }^{43}$ Cf. M. Anner, Abandoned? The Impact of Covid-19 on Workers and Businesses at the Bottom of Global Garment Supply Chains, 'Research Report Center for Global Workers' Rights' 27 March 2020.

${ }_{44}$ As it becomes apparent from the blog by Clean Clothes Campaign, op cit.; a clear example in this respect is the situation in Bangladesh, cf. T. Donaldson, Bangladesh Introduces Country-Wide Lockdown, as Factories Already Face 'Indefinite Shutdown, 'Sourcing Journal', 25 March 2020.

${ }^{45}$ A much-heard phrase by again presidents/leaders and policy makers.

${ }^{46}$ Despite arguments made to change supply chain policies and calls made for reshoring, this may not be as simple as it seems, cf. O. Antonenko and C. McGarry, What the COVID-19 pandemic means for supply chains, www.ControlRisk.com, 27 May 2020 (accessed 29 July 2020).

47 OECD, COVID-19 and Responsible Business Conduct, 'OECD Policy Responses to Coronavirus (COVID-19)', 16 April 2020, p. 11. 
Although several guidelines or self-assessment tools have been published by international ${ }^{48}$ and non-governmental organisations, ${ }^{49}$ law and consultancy firms, ${ }^{50}$ and academics ${ }^{51}$ advising MNEs on how to act in times of the COVID-19 pandemic, two reservations should be made. First, while these guidelines and tools have several aspects in common, there are also differences. In itself hardly surprising, since each of these organisations has its own aims and reasons for issuing the guidelines and tools. With such a plurality of guidelines and tools of which none is more authoritative than the other, it is not an easy task for MNEs to understand what the best or expected course of action is. Second, it is easy to say what to do afterwards, but what was expected from MNEs at the moment COVID-19 became pandemic, in other words, what were MNEs already expected to do in the CSR policies, especially with respect to their suppliers, subcontractors, etc. that are part of their production chain? This question, concerning the expected Responsible Business Conduct (RBC) will be addressed in the next section.

48 E.g. OECD, 'COVID-19 and Responsible Business Conduct' (op cit.); UN Development Programme, Human Rights Due Diligence and COVID-19: Rapid Self-Assessment for Business, available at www.undp.org; and the ILO Monitor: COVID-19 and the world of work, available at www.ilo.org, with the fifth (update) published on 30 June 2020.

${ }^{49}$ E.g. SOMO, ECCHR and PAX, op. cit.; Fair Labour Association, COVID-19 PANDEMIC GUIDANCE DOCUMENT: Workplace-Level Preparations and Safeguards, available at www.fairlabor.org; Responsible Business Alliance, Responsible Business Conduct During The Covid-19 Crisis, available at www.responsiblebusiness.org; ISO has compiled a list with measures to support efforts in dealing with COVID-19, some are also interesting from a labour law perspective, especially regarding $\mathrm{OSH}$, these are available at www.iso.org.

${ }^{50}$ E.g. Www.ControlRisk.com (op cit.); Deloitte, COVID-19 Managing supply chain risk and disruption, available at www.deloitte.com; and Price, Waterhouse, Coopers (PWC), with information and guidelines on global level (available at www.pwc.com) and per region/country; and A. Dangova Hug, Tool on (Children's) Right to Health and Businesses - Unpacking the Human Rights Due Diligence Standard, INTER PARTES Skopje (available at www.interpartes.mk - and promoted by the Business and Human Rights Resource Centre (www.business-humanrights.org)).

${ }^{51}$ For example, M. Anner, op cit.; J. Sarkis, M.J. Cohen, P. Dewick, and P. Schröder, op cit. Albeit these scholarly articles are more forward looking with the aim to prevent future vulnerable situations encountered in these times. 


\section{MNEs' responsibilities under the ILO MNE Declaration, the OECD Guidelines, and the UN Guiding Principles}

\subsection{General remarks}

To understand what could have been expected from MNEs with respect to their production chains at the time COVID-19 became pandemic, we need to understand what kind of RBC was expected from them. As already mentioned in the introduction, three international (quasi-)legal initiatives, mentioned in the title of this section, are considered the most authoritative in this sense, hence, we need to analyse their content to understand what kind of RBC was expected. ${ }^{52}$ Before analysing these initiatives, a few remarks need to be made concerning these initiatives.

The first remark concerns the fact that these initiatives are legally non-binding. Although they are directly addressed to both, states and MNEs, by nature and general understanding the organisations that have issued these initiatives can only adopt legally binding measures for states. One of the reasons for this limitation is the ongoing discussion whether MNEs have international legal personality (ILP). ${ }^{53}$ What is more, the choice of instrument, that is, declarations and guidelines, for these initiatives are in general also considered to be forms of soft law. Consequently, these initiatives are surrounded by voluntarism. In other words, states and MNEs cannot be forced to adopt and implement them and comply with these initiatives. At the same time, it does not mean that these initiatives are mere paper tigers. ${ }^{54}$ With CSR be-

52 Although their also exist regional initiatives, e.g. from the European Union, in general these initiatives follow what has been set out by these three international initiatives. Cf. B.P. ter Haar and A. Kun, The CSR-policy of the EU in a global context with specific regard to its uneven regional implementation across Europe: in 'Research Handbook on Labour, Business and Human Rights Law', J.R. Bellace and B.P. ter Haar (eds.), Cheltenham, Edward Elgar, 2019, pp. 439-465.

${ }^{53}$ See more elaborately about ILP of MNEs: A. de Jonge, Transnational Corporations and International Law. Accountability in the Global Business Environment, Cheltenham; Edward Elgar, 2011; and A. García-Muñoz Alhambra, B.P. ter Haar and A. Kun, Harnessing Public Institutions for Labour Law Enforcement. Embedding a Transnational Labour Inspectorate within the ILO, 'International Organizations Law Review', 17(2020) 233-260.

${ }^{54}$ See for an analysis of soft instruments in the context of CSR: M.A. Garcia-Munoz, B.P. ter Haar, and A. Kun, Soft on the Inside, Hard on the Outside: An Analysis of the Legal 
coming more and more the standard behaviour as expected by shareholders, stakeholders, and consumers, these initiatives are increasingly incorporated in other, legally binding, initiatives, such as procurement law, free trade agreements, and specific regional ${ }^{55}$ and national laws on child labour, ${ }^{56}$ forced labour ${ }^{57}$ and, increasingly, on due diligence. ${ }^{58}$ This effect is also referred to as the hardening of soft law ${ }^{59}$ and, as a result, they have, at least, a normative effect on the (legal) practices of states and MNEs. Therefore, it seems apt to analyse such initiatives in order to understand what kind of behaviour they require from MNEs in general, and consequently, also in these times of the COVID-19 pandemic.

Secondly, it should be noted that these initiatives seem not to operate in isolation from one another. On the contrary, following the idea of hybrid global governance, that is, the acknowledgement of a global

Nature of New Forms of International Labour Law, 'International Journal of Comparative Labour Law \& Industrial Relations' 2011, 27(4), p. 337-363. See for a conclusion in similar vein: J.R. Bellace, From workers' rights to human rights at work in: 'Research Handbook on Labour, Business and Human Rights Law', J.R. Bellace and B.P. ter Haar (eds.) Cheltenham, Edward Elgar 2019, p. 402-420.

55 The European Union for example has adopted Directive 2014/95/EU amending Directive 2013/34/EU as regards disclosure of non-financial and diversity information by certain large undertakings and groups (OJ[2014]L330/1) and works on a specific directive on due diligence: responsiblebusinessconduct.eu/wp/2020/04/30/european-commissionpromises-mandatory-due-diligence-legislation-in-2021/ (accessed 1 August 2020).

${ }^{56}$ E.g. in 2017 The Netherlands adopted the Child Labour Due Diligence Law: www.business-humanrights.org/en/dutch-companies-issue-open-letter-in-support-ofchild-labour-regulation (accessed 1 August 2020).

57 E.g. in 2015 The UK adopted the Modern Slavery Act: https://www.legislation. gov.uk/ukpga/2015/30/contents/enacted (accessed 1 August 2020).

58 E.g. in 2017 France adopted the Law on Due Vigilance: https://www.business-humanrights.org/en/france-natl-assembly-adopts-law-imposing-due-diligence-on-multinationals-to-prevent-serious-human-rights-abuses-in-their-supply-chains (accessed 1 August 2020); and by the end of 2020 a referendum is planned in Switzerland to adopt a law on due diligence: N. Bueno, The Swiss Popular Initiative on Responsible Business From Responsibility to Liability, in: 'Accountability and International Business Operations: Providing Justice for Corporate Violations of Human Rights and Environmental Standards', L.F.H. Enneking, I. Giesen, F.G.H. Kristen, L. Roorda, C.M.J. Ryngaert, A.L.M. Schaap (eds.), London, Routledge, 2018; and for a more general overview of national legislative CSR obligations: N. Bueno, Multinational enterprises and labour rights: concepts and imlementation, in: 'Research Handbook on Labour, Business and Human Rights Law', J.R. Bellace and B.P. ter Haar (eds.) Cheltenham, Edward Elgar, 2019, p. 421-438.

${ }^{59}$ Similar: J. Hughes, L. Hamzi and R. Mashru, op cit. 
space in which various regulatory activities coexist in various interactions with each other, these three initiatives seem to be complementary to one another and even show signs of transformation, rather than being rivalry. ${ }^{60}$ This means that the combined expectations laid down in these initiatives plays to each other's strengths ${ }^{61}$ and hence the meaning of these initiatives in terms of normative effect on the (legal) practice of States and MNEs. Moreover, and as third and last preliminary remark, it should be noted that it seems that MNEs refer to these initiatives in their CSR policies. ${ }^{62}$ Sometimes directly, sometimes indirectly. In a previous study on these initiatives I found that out of the twenty MNE CSR codes of conduct included in the research sample, only four of them (4) made no reference at all to any of those initiatives. ${ }^{63}$ Regarding International Framework Agreements (IFAs), all those included in the sample refer to at least one of the initiatives central in this section. ${ }^{64}$ Thus, albeit with some reservations, it can therefore be presumed that these initiatives do matter in MNEs' CSR practices. Therefore, it makes sense to analyse the content of these initiatives to understand what behaviour of MNEs could have been expected regarding the situation of the COVID-19 pandemic.

Having established that the three initiatives central in this section matter for the MNEs' CSR practices it is time to turn to their content. More particularly, the analysis of the three initiatives will be focussed on the four aspects identified in the previous section, in short: 1. COVID-19 OSH-measures; 2. human trafficking and forced labour; 3. engagement in terms of a. complying with or respecting contracts and $\mathrm{b}$. preserving jobs and securing incomes; and 4. use of a resilient (production) demand system (instead of JIT).

\subsection{COVID-19 OSH-measures}

Of course, we cannot expect to find specific COVID-19 OSH measures in the initiatives, however, we can analyse to what extend it was

${ }^{60}$ Cf. B.P. ter Haar, Love, Flirt or Repel: Hybrid global governance of the ILO core labour standards, 'European Journal of Social Law' 2013, Vol. 2, p. 68-102.

${ }^{61}$ Ibidem.

${ }^{62}$ Ibidem.

${ }^{63}$ Ibidem, 95-96.

${ }^{64}$ Ibidem, 99. 
to be expected that MNEs would have included OSH as part of their $\mathrm{RBC}$. Such would for example be the case if OSH in general is acknowledged as one of the material issues that should be covered by their CSR policies. In general, the OECD Guidelines and the UNGPs cover the ILO's core or fundamental labour standards, ${ }^{65}$ i.e. the abolition of forced labour and child labour, equality of opportunity and treatment, and the freedom of association, including the right of collective bargaining. These standards have been declared as fundamental by the ILO in its 1998 Declaration on Fundamental Principles and Rights at Work. ${ }^{66}$ More interestingly, in its follow-up document to the 1998 Declaration, the ILO included an annual review procedure for all Member States that have not ratified the Conventions dealing with these fundamental standards. ${ }^{67}$ The underlying idea is that these standards are core or fundamental to achieve the ILO's mission as set out in its Constitution and the Philadelphia Declaration. ${ }^{68}$

While in scholarly debate the 1998 Declaration was received with mixed expectations, ${ }^{69}$ interesting for our analysis is that if MNEs make references to ILO documents in their CSR policies, by far most of them are made to the 1998 Declaration. ${ }^{70}$ As such, Langille's argument that the 1998 Declaration would make it more easy for States and other actors to pick up on these principles and standards, proved to be right. However, there is also some sence in Alston's comments, because the practice of referring to the 1998 Declaration has resulted in significantly less attention for any of the other standards, with OSH being one of them.

${ }^{65}$ Commentary 39 OECD Guidelines; and Principle 12 UN GPs.

${ }^{66}$ Available at www.ilo.org/declaration/lang--en/index.htm.

${ }^{67}$ ILO Rules of the Game An introduction to the standards-related work of the International Labour Organization (Centenary edition 2019), available at www.ilo.org, p. 120.

${ }^{68}$ Preamble and Article 1 of the 1998 Declaration.

$69 \mathrm{Ph}$. Alston, "Core Labour Standards" and the Transformation of the International Labour Rights Regime, 'European Journal of International Law' 2004, 15(3), p. 457-521; B.A. Langille, Core Labour Rights - The True Story (Reply to Alston), 'European Journal of International Law', 2005, 16(3), p. 409-437; F. Maupain, Revitalization not Retreat. The Real Potential of the 1998 ILO Declaration for the Universal Protection of Workers' Rights, 'European Journal of International Rights', 2005, 16(3), p. 439-465; and Ph. Alston, Facing Up the Complexities of the ILO's Core Labour Standards Agenda, 'European Journal of International Law' 2005, 16(3), p. 467-480.

${ }^{70}$ Cf. Ter Haar, op cit. 
In addition to the ILO's fundamental labour standards, the OECD Guidelines and the UN GPs also refer to the UN's International Covenant on Economic, Social and Cultural Rights, ${ }^{71}$ which does include OSH. ${ }^{72}$ The OECD Guidelines also refer to the ILO's MNE Declaration, albeit more for its terminology rather than material content. ${ }^{73}$ Additionally, when it comes to the ILO and CSR, it is not the 1998 Declaration that is the most relevant initiative, indeed it is the MNE Declaration. ${ }^{74}$ The MNE Declaration is contextualised in the setting of the ILO's Decent Work Agenda. ${ }^{75}$ The Decent Work Agenda is based on four pillars (employment creation, social protection, rights at work, and social dialogue), which resonates well with the UN's 2030 Sustainable Development Goals (SDGs), especially SDG $8 .{ }^{76}$ In its Centenary Declaration $^{77}$ the ILO seems to move even further away from a "fundamental labour standards promoting approach," towards a more integral approach based on an inclusive interpretation of Decent Work. ${ }^{78}$ From all this there are two takeaways that are relevant to our analysis. Firstly, the MNE Declaration includes OSH (and working time) as part of "Conditions of work and life."79 Secondly, with a (seemingly) shift from a fundamental labour standards centred promotional approach to a more integral and inclusive decent work approach, MNEs are expected to follow a more integral and inclusive approach as well.

In addition to the above, if we take a wider approach and review research on CSR and OSH, we find a number of studies dealing particularly with the topic in question. One of them is interesting to us, ${ }^{80}$ since it illustrates that the influence on MNEs' CSR policies is clearly

${ }^{71}$ Commentaries par. 39 OECD Guidelines; and Commentary on Principle 12 UN GPs.

72 Art. 7(b) ICESCR (available at: www.ohchr.org).

${ }^{73}$ Paras. 48-49 Commentaries OECD Guidelines.

${ }^{74}$ Available at: www.ilo.org/empent/areas/mne-declaration/WCMS_570332/lang-en/index.htm.

${ }^{75}$ For a brief explanation about Decent Work see: www.ilo.org/global/topics/de cent-work/lang--en/index.htm (accessed 1 August 2020).

${ }^{76}$ See more about the SDGs at sdgs.un.org/goals (accessed 1 August 2020).

77 ILO Centenary Declaration for the Future of Work, adopted by the Conference at its One Hundred And Eighth Session, Geneva, 21 June 2019, available at www.ilo.org.

${ }_{78}$ Cf. Par. B, Section I Centenary Declaration.

79 Articles 42-47 MNE Declaration.

${ }^{80}$ M.J. Montero, R.A. Araque, J.M. Rey, Occupational health and safety in the framework of corporate social responsibility, 'Safety Science' 2009, Vol. 27, p. 1440-1445. 
not limited to these three initiatives ${ }^{81}$ In their study Montero et al. give special relevance to SA8000. ${ }^{82}$ Taking this one step further and performing a very brief check on to what extend we find $\mathrm{OSH}$-issues in MNE's CSR policies, we can see that it seems to be more often part of it than not. For this assessment I have relied on two sources. The first is a list of IFAs included in the Appendix in a book on the impact of IFAs. ${ }^{83}$ Out of the 82 IFAs that are listed, 64 (which is $78 \%$ ) include OSH-issues and 48 (which is 58\%) include working time. ${ }^{84}$ The second is the database available at www.csrhub.com, which rates and ranks MNEs on several aspects of CSR, including "Employees" which, in turn, includes OSH..$^{85}$ Interestingly, the impression we can get from data that is freely available ${ }^{86}$ is that $\mathrm{OSH}$ is relatively often part of the CSR policies. ${ }^{87}$

To conclude, in terms of expected responsible business conduct based on the OECD Guidelines, the UN GPs and the ILO MNE Declaration it is to be expected that MNEs consider OSH as part of their CSR. That this is indeed the fact, in practice seems to be confirmed by the very brief assessment of (very limited) available data of two sources.

\subsection{Human trafficking and forced labour}

Compared to $\mathrm{OSH}$, human trafficking and forced labour is much easier to identify in the context of CSR, since it is one of the four labour standards that have been declared fundamental by the ILO. Hence, all three initiatives include the abolition of forced labour among the topics they promote. ${ }^{88}$ All three make general references to the ILO Conven-

${ }^{81}$ Not that I have claimed this, but it underlines the limitation of this study with a focus on only these three initiatives.

82 See at sa-intl.org/programs/sa8000/.

${ }^{83}$ K. Papadakis (ed.), Shaping Global Industrial Relations. The Impact of International Framework Agreements. New York, Palgrave MacMillan, 2011.

${ }^{84}$ Ibidem, Table 2 Substantive provisions in international framework agreements.

${ }^{85}$ esg.csrhub.com/csrhub-data-schema (accessed 2 August 2020).

${ }^{86}$ Which is far from representative, but it is about what the inclusion of $\mathrm{OSH}$ as key aspect signals.

87 content.csrhub.com/files/dash/CSRHub+Dashboard+Competitor+Benchma rk--2019-03-28.pdf (accessed 2 August 2020).

${ }^{88}$ More specifically: Guideline V1d) OECD Guidelines; Commentary on Guiding Principle 12 UN GPs; and General Principle 9 and for MNEs specifically Principle 25 ILO MNE Declaration. 
tions on forced labour, namely, C29 and C105. Apart from the Conventions, the ILO has also adopted two Recommendations (R35 and R203) and a Protocol (P29) on the issue of forced labour. ${ }^{89}$ Forced labour is defined as "all work or service which is exacted from any person under the menace of any penalty and for which the said person has not offered himself voluntarily." 90 The question is whether forced labour as understood by the ILO also includes human trafficking, particularly in relation to migrant workers. ${ }^{91}$

Convention C29 does not mention trafficking, however, Article 1(3) P29 repeats the definition of C29 and adds to this that it also includes government action "against trafficking in persons for the purposes of forced or compulsory labour." However, none of the CSR initiatives address migrant workers or a more specific duty to care for migrant workers, who, as is common knowledge, often are in a position that makes them vulnerable for trafficking and forced labour. Moreover, Principle 18 of the ILO's MNE Declaration stipulates that MNEs "should give priority to the employment, occupational development, promotion and advancement of nationals of the host country at all levels in cooperation [...]." And although this is understandable from the assumption that outsourcing activities of MNEs (also) have a positive impact, ${ }^{92}$ the focus on nationals of the host country inherently includes the risk of deterring attention from migrant workers. Of course, such topics as human trafficking and forced labour are not limited to country nationals only, however, there is also no particular incentive to direct activities to prevent or mitigate adverse impacts on migrant workers.

Coming back to the topic of forced labour, we can see that Article 2(e) P29 requires states to adopt measures that support "due diligence by both the public and private sectors to prevent and respond to risks of forced or compulsory labour." Something only a few states have acted upon, as indicated in the preliminary remarks to this section. In the ILO's MNE Declaration we can read that companies are expected to "take immediate and effective measures within their own competence to secure the prohibition and elimination of forced or compulsory la-

89 All available in Normlex at www.ilo.org.

90 Art. 2(1) C29.

${ }^{91}$ Migrant workers since they have been identified as the workers most at risk of forced labour in these times of the COVID-19 pandemic (see above).

92 Principle 1 ILO MNE Declaration. 
bour in their operations." ${ }^{93}$ How they should do this is worked out in Principle 10, which refers to the UN GPs (as do the OECD Guidelines ${ }^{94}$ ), among which is (included) the role of MNEs to respect human rights. ${ }^{95}$ Based on all the three initiatives, MNEs are required to: "(i) avoid causing or contributing to adverse impacts through their own activities, and address such impacts when they occur; and (ii) seek to prevent or mitigate adverse human rights impacts that are directly linked to their operations, products or services by their business relationships, even if they have not contributed to those impacts." ${ }^{\prime 96}$ MNEs "should carry out due diligence to identify, prevent, mitigate and account for how they address their actual and potential adverse impacts that relate to internationally recognized human rights." ${ }^{\prime 97}$ In order to address the identified adverse impacts (or risks) MNEs are encouraged to have meaningful consultations with stakeholders, especially with trade unions or other forms of workers representation doing justice to the freedom of association and collective bargaining. ${ }^{98}$ However, the UN GPs and OECD Guidelines only mention "stakeholders" without a direct specification of the role of workers' representatives. ${ }^{99}$ Indirectly a reference to a role as stakeholder by workers' representatives can be found in the explanation on how the OECD Guidelines and the MNE Declaration are linked to each other:

The OECD Guidelines and the ILO MNE Declaration refer to the behaviour expected from enterprises and are intended to parallel and not conflict with each other. The ILO MNE Declaration can therefore be of use in understanding the Guidelines to the extent that it is of a greater degree of elaboration. ${ }^{100}$

${ }^{93}$ Principle 25 ILO MNE Declaration.

${ }^{94}$ Commentary 36 OECD Guidelines.

${ }^{95}$ Which stems from the Ruggie Framework "Protect, Respect, Remedy" and that forms the backbone of the UN GPs. Cf. General Guiding Principle of the UN GPs.

${ }^{96}$ Principle 10(c) ILO MNE Declaration; Guiding Principle 13 UN GPs, which are the same as General Policies Guidelines 11 and 12 and Commentaries 17-20 OECD Guidelines.

97 Principle 10(d) ILO MNE Declaration; Guiding Principles 17, 18 and 19 UN GPs, and resonates Guideline 10 and Commentaries 14, 15 and 16 OECD Guidelines.

${ }_{98}$ Principle 10(e) ILO MNE Declaration.

${ }^{99}$ Cf. Guiding Principle 18(b) UN GPs; and Guideline 14 OECD Guidelines

100 Commentary 48 OECD Guidelines. 
To summarise, MNEs are expected to deal with the issue of human trafficking and forced labour, as in not to contribute to it directly or to prevent or mitigate it when indirectly involved. The way they are expected to do this is via activities that meet the requirements of due diligence and involve stakeholders, among which workers' representatives.

\subsection{Engagement}

The issue of engagement is divided into two topics. The first one concerns compliance with or respecting contracts rather than using force majeure as an argument to terminate contracts at any stage. The second topic is the preservation of jobs and securing incomes when it is not possible to keep workers employed.

The first topic, respecting supplier contracts, is actually a question of engagement, or better of disengagement. On first glance the OECD Guidelines give us the best insight into this issue. ${ }^{101}$ The most relevant text we can find in the OECD Guidelines is Commentary 22, which gives further explanation to the expectation of MNEs to prevent or mitigate their direct and indirect adverse impacts on human rights. The commentary reads as follows:

Appropriate responses with regard to the business relationship may include continuation of the relationship with a supplier throughout the course of risk mitigation efforts; temporary suspension of the relationship while pursuing ongoing risk mitigation; or, as a last resort, disengagement with the supplier either after failed attempts at mitigation, or where the enterprise deems mitigation not feasible, or because of the severity of the adverse impact. The enterprise should also take into account potential social and economic adverse impacts related to the decision to disengage.

Relevant in the context of this study is that this commentary makes clear that disengagement is considered to be a measure of last resort. If

101 The UN GPs only refer to an? MNE/MNEs? to use its leverage to prevent or mitigate adverse impacts on human rights. When such is really not possible, an MNE should terminate (dis-engage) its involvement. Cf. GP 19 and commentary UN GPs. Since on this point the ILO MNE Declaration refers to the UN GPs it provides no further insights. 
all efforts to mitigate fail, then disengagement could maybe be considered. On top of this, the enterprise should also take into account social and economic adverse impacts that will be the consequence of the disengagement. The OECD Guidelines and the UN GPs have additional explanatory documents regarding due diligence and exercising leverage. ${ }^{102}$ The additional guidance on disengagement is not very helpful as it merely repeats what is already in the explanatory commentaries to the guidelines, however, the UN Working Groups document refers to a discussion paper published by SOMO entitled "Should I stay or should I go?" which explores the role of disengagement in human rights due diligence. ${ }^{103}$ In this document it is more clearly stated that

[j] ust as with any business decision, the UNGPs and OECD Guidelines expect companies to conduct due diligence on potential adverse impacts of disengagement. That is, they should identify potential adverse human rights impacts resulting from the decision to disengage and seek to prevent or mitigate those potential impacts. ${ }^{104}$

Adverse impacts include for instance loss of jobs for workers, loss of tax revenues, and other potential local economic impacts resulting from a hasty departure. ${ }^{105} \mathrm{~A}$ simple application of these expectations to the COVID-19 pandemic situation in which MNEs have terminated supplier contracts abruptly would lead to the conclusion that this is at least a form of irresponsible disengagement. However, when reviewing these expectations in the wider context of human rights due diligence, these rules seem to apply only in the situation of adverse impacts on human rights. The COVID-19 pandemic has adverse impacts on human rights, but not the kind that is meant by these rules. Hence, the question remains whether COVID-19 as such could count

102 For the UN GPs this is the report to the UN's General Assembly by the Working Group on the issue of human rights and transnational corporations and other business enterprises, submitted pursuant to Human Rights Council resolutions 17/4 and 35/7, 16 July 2018, available at www.ohchr.org; and for the OECD Guidelines this is the OECD Due Diligence Guidance for Responsible Business, available at https://mneguidelines.oecd.org.

${ }^{103}$ Dated April 2016 and available at www.somo.nl.

104 SOMO, Should I stay or should I go?, Discussion Paper (April 2016), 6 (available at www.somo.nl).

105 Ibidem. 
as a cause for disengagement in the context of these guidelines. If yes, there is an expectation that they disengage in a responsible manner, if no, COVID-19 is not an accepted cause for disengagement at all and the expectation is that MNEs would simply stay engaged.

Although the guidelines in the three initiatives are not decisive in what is to be expected from MNEs in general terms of engagement, it can be concluded that either COVID-19 is no cause for disengagement, and if it is it should be done in a responsible, so a due diligence manner. With this in mind we can now move on to the second issue: preserving jobs and securing incomes.

One of the consequences of disengagement, or termination of supplier contracts, is that many suppliers had to terminate employment relationships with their workers. This had (and at the moment of writing this article, still has) a huge impact on the lives of those workers since the loss of the job also means the loss of the only or main source of income. ${ }^{106}$ In many home countries of the suppliers there are no alternative sources of income such as unemployment benefits or social assistance. ${ }^{107}$ In some countries this has resulted in not only a health and economic crisis, but also in a humanitarian crisis. ${ }^{108}$ Hence the strong call on MNEs to preserve jobs and secure incomes. But what is expected from MNEs on this? We already know there is some expectation of MNEs to stay engaged with their suppliers and that disengagement may either not be acceptable under human rights due diligence or subject to an assessment on the adverse impacts of it. But what about the obligation of MNEs to preserve jobs and secure incomes?

The OECD Guidelines and UN GPs do not address this at all. Not a surprise, since materially their scopes are limited to the ILO's fundamental labour standards. ${ }^{109}$ If any thing could be found in these two initiatives it is only by a positive interpretation of the prohibition of

106 Cf. Clean Clothes Campaign, Garment workers need apparel companies' assurance that they will be paid during this crisis, published 1 June 2020, available at cleanclothes.org.

107 See above. See also: A video by Guy Ryder Social protection a vital part of the pandemic response (available at www.ilo.org - COVID-19 and social protection); and more generally the ILO's webpage on social protection where it is stated that merely $27 \%$ of workers around the world have access to social protection: www.ilo.org/global/topics/ social-security/lang--en/index.htm (accessed 3 August 2020).

${ }^{108}$ L. Schnirring, Global COVID-19 total nears 14 million amid appeal for nations in crisis, 'CIDRAP News' 17 July 2020.

109 See above on the issue of OSH. 
forced labour, namely, the right to freely choose work and with that a positive obligation for states to make efforts to achieve full employment. ${ }^{110}$ However, this is an expectation of the behaviour of States, what about MNEs? Principle 16 of the ILO's MNE Declaration stipulates that MNEs, "particularly when operating in developing countries, should endeavour to increase employment opportunities and standards." Moreover, in terms of income security, MNEs are stimulated to complement "ublic social security systems and help to stimulate further their development, including through their own employersponsored programmes." 111 The most interesting principle in the ILO's MNE Declaration though is number 33 which reads as follows:

Multinational enterprises as well as national enterprises, through active employment planning, should endeavour to provide stable employment for workers employed by each enterprise and should observe freely negotiated obligations concerning employment stability and social security. In view of the flexibility which multinational enterprises may have, they should strive to assume a leading role in promoting security of employment, particularly in countries where the discontinuation of operations is likely to accentuate long-term unemployment.

Providing stable employment and promoting security of employment could be interpreted as "preserving jobs." Albeit such an interpretation is reserved for the ILO's Governing Body, ${ }^{112}$ it may not be too much of a stretch. Particularly not when reading it in conjunction with Principle 34, which resonates the due diligence approach of the general expectations on disengagement. ${ }^{113}$

${ }_{110}$ Cf. Article 11 ILO Recommendation R205 - Employment and Decent Work for Peace and Resilience Recommendation (2017).

111 Principle 22 ILO MNE Declaration.

112 Annex 2 to the ILO MNE Declaration Operational Tools, Section 3 Procedure for the examination of disputes concerning the application of the Tripartite Declaration of Principles concerning Multinational Enterprises and Social Policy by means of interpretation of its provisions (interpretation procedure).

113 Principle 34 ILO MNE Declaration reads: “In considering changes in operations (including those resulting from mergers, takeovers or transfers of production) which would have major employment effects, multinational enterprises should provide reasonable notice of such changes to the appropriate government authorities and representatives of the workers in their employment and their organizations so that the im- 


\subsection{Replacing just-in-time management with a resilient (production) demand system}

The last issue that surfaced during the COVID-19 pandemic is the call for a more resilient (production) demand system. The current prevailing system of Just-In-Time (JIT) management has proven to be vulnerable in two ways: instant shortages of (essential) products and immediate cancellation of orders (termination of contracts with suppliers, resulting in many instances of the termination of employment contracts). ${ }^{114}$ So, the question has to be asked: What is expected from MNEs in this respect?

To understand what is expected from MNEs in terms of management strategy, we have to first look at what is exactly understood by human rights due diligence. As Trebilcock has showed in her disquisition of due diligence, human rights due diligence is not the same as how due diligence is understood in corporate law. ${ }^{115}$ The first paragraph of explanation to Guiding Principle 18 of the UN GPs ${ }^{116}$ is very instrumental in understanding this. In full it reads:

The initial step in conducting human rights due diligence is to identify and assess the nature of the actual and potential adverse human rights impacts with which a business enterprise may be involved. The purpose is to understand the specific impacts on specific people, given a specific context of operations. Typically this includes assessing the human rights context prior to a proposed business activity, where possible; identifying who may be affected; cataloguing the relevant human rights standards and issues; and projecting how the proposed activity and associated business relationships could have adverse human rights impacts on those identified.

plications may be examined jointly in order to mitigate adverse effects to the greatest possible extent. This is particularly important in the case of the closure of an entity involving collective lay-offs or dismissals."

${ }^{114}$ See section 2.

115 A. Trebilcock, Due Diligence on labour issues - Opportunities and limits of the UN Guiding Principles on Business and Human Rights, in: 'Research Handbook on Transnational Labour Law, A. Blackett and A. Trebilcock (eds), Cheltenham, Edward Elgar, 2015, p. 93-107.

116 Similar to engagement the ILO's MNE Declaration does not add much to this as it refers to the UN GPs on this point. 
Essential in this explanation is that typical for the first step in human rights due diligence is that the MNE assesses the human rights context prior to a proposed business activity. One caveat though. From the quoted fragment it is not clear what is meant by "a proposed business activity" or business operations. The OECD is more elaborate on this in point 2.1 of the Due Diligence Guidance for Responsible Business Conduct which clarifies that MNEs are expected "to carry out a broad scoping exercise to identify in all areas of the business, across its operations and relationships, including in its supply chains, where RBC risks are most likely to be present and most significant." This includes, among others, information about sectoral, geographic, product, and enterprise risk factors. Information about sectoral elements could for example be "products and their supply chains, services and other activities," and about geography "governance and rule-of-law, conflict, pervasive human rights or environmental adverse impacts."117 It becomes clearer in the last point on "practical actions," which is about updating the assessment when the MNE changes something in its operations, such as "operating in or sourcing from a new country; developing a new product or service line that varies significantly from existing lines; changing the inputs of a product or service; restructuring, or engaging in new forms of business relationships (e.g. mergers, acquisitions, new clients and markets)." 118

What we get from this is that "business operations" does not seem to include impacts of the modus operandi applied in the execution of the activities. Hence, it does not seem to require an impact assessment of the model that is used to govern the activities, such as JIT management. If I understand this correctly, it is a serious shortcoming of these guidelines. Not only has the COVID-19 pandemic exposed the consequence of JIT management in times of crisis, but also from a labour rights point of view several adverse impacts are obvious consequences of JIT management as modus operandi.

As already elaborated on in Section 2, the JIT management is characterised as a production on demand system to minimise stocks. Consequently, orders are placed as late as possible resulting in high time pressure on the production. Part of the JIT management also involves

117 Point 2.1, sub b OECD Due Diligence Guidance for Responsible Business Conduct.

118 Ibidem. Point 2.1, sub g. 
short-term contracts with suppliers. It is not uncommon that per production activity a separate commission contract is concluded. This makes it difficult for suppliers to manage their workload. One effect is that suppliers overbook themselves which results in sub-contracting practices to among others, companies that do not care much about human rights (sometimes characterised as sweatshops) or to homeworkers (which enhances the risk of child labour). Another effect is that (excessive) overtime needs to be made to meet the production deadlines, and it is a well-known fact that the number of workplace accidents grows exponentially with the number of working hours. A last effect to mention here is that because the supplier operates in uncertainty about commissions, he, as an employer, is limited in his options to engage in secure employment relationships with the majority of his workers. Hence, many workers have to enter into short-time contracts.

The picture that we see emerge from JIT management as modus operandi for the business operations is one filled with uncertainty and (potential) adverse impacts on human rights. Moreover, it affects three out of the four issues addressed in this article: OSH; engagement; and employment security. Unfortunately, this is an under-researched topic in labour law, which makes it difficult to substantiate these adverse impacts of JIT management. ${ }^{119}$ However, even when this cannot be substantiated, due diligence requires MNEs to "identify, prevent, mitigate and account for how they address their actual and potential adverse impacts [...]." 120 The relevant word here is "potential" adverse impacts resulting from the MNEs' activities. Potential refers to the impact it could have even though it has not manifested itself yet. The question is whether "potential" also refers to impacts that exists in theory only. There are no clear indications for the latter, but even if there were, it would not help us much, because the term "business operations" doesn't encompass the modus operandi of those activities. As such the conclusion must be that there is no expectation of MNEs to change JIT management as their main modus operandi into a less volatile demand system that is more resilient and fits the 21st century.

119 In fact, I am not aware of any study making these links so clear, also not in other disciplines.

${ }^{120}$ Commentary 14 OECD Guidelines. 


\section{Concluding remarks}

Following strong moral appeals to MNEs to behave socially responsible regarding their supply chains, we started with the question what kind of RBC is expected from MNEs in these times of the COVID-19 pandemic. The focus of this question are labour rights. To understand what MNEs are called upon to do we analysed those calls and translated them into labour rights issues. By tracing ruptures in production processes, it was possible to identify the labour rights issues, albeit in sketchy manner. The issues that kept surfacing in this analysis are: occupational safety and health $(\mathrm{OSH})$, including coping with peak working hours for those who have to work during the times of COVID-19, and PPE; and a reduction in working hours resulting in furloughing or (partial) termination of the employment relationship. As third issue mentioned by some is a heightened risk of human trafficking and forced labour. For the purpose of the analysis in Section 3 these issues were re-formulated in terms of expected RBC in times of the COVID-19 pandemic.

With respect to the first expected $\mathrm{RBC}$, to ensure all necessary COVID-19 OSH-measures are taken and followed for those that continue to work, we found that $\mathrm{OSH}$ in general is a recognised subject of CSR. Even though it is not a fundamental labour standard, it is one of the topics covered by the ILO's MNE Declaration. Moreover, it is a topic that can be found in many MNEs' CSR policies. Being a recognised topic of CSR (or RBC) in the law in the books as well as in the law in practice, it is an RBC that can be expected from MNEs.

Devoting special attention to human trafficking and forms of forced labour, especially to migrant workers who are in a heightened vulnerable position is the second expected RBC. There is no doubt that forced labour is part of the CSR issues since it is one of the four fundamental labour standards. Because all instruments refer to the ILO Conventions and Recommendations, this also applies for the interpretation whether forced labour to also includes human trafficking. However, migrant workers as a target group requiring special attention are not mentioned. We could reason that it is not necessary because they would get on the radar by dealing with the issues human trafficking and forced labour. However, the strong focus on country nationals seems to divert attention from migrant workers. Therefore, it is doubtful whether 
MNEs can be expected to have special attention for the (heightened vulnerable) position of migrant workers, which is the main issue here. The third RBC concerns issues of engagement with the suppliers. In this respect we found that in general there exists a strong expectation of MNEs to stay engaged in order to prevent or mitigate adverse impacts of their business activities: disengagement is considered to be a measure of last resort. Furthermore, if an MNE decides to disengage with its supplier, it needs to assess the social and economic adverse impacts thereof in accordance with the rules of due diligence. Adverse impacts include, among other things, loss of jobs, loss of tax revenues, and other potential local economic impacts resulting from a hasty departure. This is exactly what happened during the COVID-19 pandemic. There is one caveat though: the question is whether the COVID-19 pandemic counts as a human right giving cause to disengagement. After all, it are human rights impacts that give rise to preventive and mitigating activities, which eventually may result in disengagement. If COVID-19 can be considered as giving cause for disengagement, the expectation is that it is done in a responsible manner. If COVID-19 cannot be considered as giving cause for disengagement, the expectation is that the MNE stays engaged, after all there is no (human rights) reason for disengagement. Whatever it is, abrupt disengagement, as is shown during the COVID-19 pandemic, is not the expected RBC.

The second subject of engagement that was addressed is the issue of preservation of jobs and securing of income. Here we found that the ILO's MNE Declaration expects MNEs to contribute to both. More particularly, MNEs are expected to provide stable employment, or at least promote security of employment, and to complement "public social security systems and help to stimulate further their development, including through their own employer-sponsored programmes."121 This leaves ample room to understand that RBC requires MNEs to care about their suppliers in times of the COVID-19 pandemic. Especially when combined with the general expectation of engagement.

Any expectations to change the JIT management system into a less volatile demand system that is more resilient and fits the 21st century, have perished in our analysis. Although MNEs have to assess the adverse impacts of their business activities or operations, this seems not

${ }^{121}$ Principle 22 ILO MNE Declaration. 
to include also the modus operandi. The examples given of activities that should be assessed make clear that modus operandi is not among them. From a labour rights point of view this seems a serious shortcoming. JIT management is a cause of several (potential) adverse impacts on labour rights, including (excessive) overtime, workplace accidents, employment insecurity and weak engagement. All issues that we also identified as issues of RBC MNEs are called upon in this time of the COVID-19 pandemic. The pandemic has merely made these issues more conspicuous, but they are not new and seem to be inherent to JIT management. This makes the exclusion of modus operandi as business operation even more of a serious shortcoming in current CSR policies. For now, the conclusion must be that there is no expectation of MNEs to change JIT management as their main modus operandi in a less volatile demand system that is more resilient and fits the 21st century. All in all, it is clear that there is more than merely a moral obligation, indeed there is a (quasi-)legal obligation for MNEs to behave as responsible businesses even, or especially, in these harsh times of the COVID-19 pandemic.

\section{Bibliography}

Alston, Ph., "“Core Labour Standards" and the Transformation of the International Labour Rights Regime', 15(3) European Journal of International Law (2004), 457-521.

Alston, Ph., 'Facing Up the Complexities of the ILO's Core Labour Standards Agenda', 16(3) European Journal of International Law (2005), 467-480.

Anner, M., 'Abandoned? The Impact of Covid-19 on Workers and Businesses at the Bottom of Global Garment Supply Chains', Research Report Center for Global Workers' Rights 27 March 2020.

Antonenko, O., and McGarry, C., 'What the COVID-19 pandemic means for supply chains', www.ControlRisk.com, 27 May 2020.

Asian Development Bank, 'Global Shortage of Personal Protective Equipment amid COVID-19: Supply Chains, Bottlenecks, and Policy Implications', ADB Briefs 130, April 2020.

Baldwin, R. and Freeman, R., 'Supply chain contagion waves: Thinking ahead on manufacturing 'contagion and reinfection' from the COVID concussion', VoxEU.org 1 April 2020.

Barro, J. The Companies That Stand to Profit from the Pandemic', New York Intelligencer 14 April 2020.

Belapatiño c.s., 'The COVID-19 impact on Consumption in Real Time and High Definition', BBVA Research 24 April 2020. 
Bellace, J.R., 'From workers' rights to human rights at work', in J.R. Bellace and B.P. ter Haar (eds.), Research Handbook on Labour, Business and Human Rights Law (Cheltenham, Edward Elgar) 2019, 402-420.

Bueno, N., 'The Swiss Popular Initiative on Responsible Business From Responsibility to Liability', in L.F.H. Enneking, I. Giesen, F.G.H. Kristen, L. Roorda, C.M.J. Ryngaert, A.L.M. Schaap (eds.), Accountability and International Business Operations: Providing Justice for Corporate Violations of Human Rights and Environmental Standards, (London: Routledge) 2018.

Bueno, N., 'Multinational enterprises and labour rights: concepts and imlementation', in J.R. Bellace and B.P. ter Haar (eds.), Research Handbook on Labour, Business and Human Rights Law (Cheltenham, Edward Elgar) 2019, 421-438.

Cheng, A. 'P\&G Says 17,600 Products Could Be Affected By Coronavirus In China, Highlighting Supply Chain Risk', Forbes 20 February 2020.

Chongvilaivan, A., 'Thailand's 2011 flooding: Its impact on direct exports and global supply chains', ARTNeT Working Paper Series, No. 113.

Christensen, J. 'Coronavirus outbreak in China could lead to 'critical' shortages of medical products in the US', CNN 26 February 2020.

Clean Clothes Campaign, 'COVID-19 Demands in defence of Garment Workers in Global Supply Chains', 18 May 2020, available at: cleanclothes.org/ news/2020/covid-19-short-term-demands-in-defense-of-garment-workersin-global-supply-chains.

Clean Clothes Campaign, 'Garment workers need apparel companies' assurance that they will be paid during this crisis', published 1 June 2020, available at cleanclothes.org.

Conaghan, J., Fischl, R.M., and Klare, K. (eds.), Labour Law in an Era of Globalization. Transformative Practices \& Possibilities (Oxford: OUP) 2002.

Craig, J.D.R. and Lynk, S.M., Globalization and the future of labour law, (Cambridge: CUP) 2006.

Dangova Hug, A., Tool on (Children's) Right to Health and Businesses - Unpacking the Human Rights Due Diligence Standard, INTER PARTES Skopje (available at www.interpartes.mk - and promoted by the Business and Human Rights Resource Centre (www.business-humanrights.org)).

Davey, M. 'From batteries to shutters: Australian firms eye potential coronavirus shortages', The Guardian 21 February 2020.

Deloitte, COVID-19 Managing supply chain risk and disruption, available at www.deloitte.com.

Donaldson, T., 'Bangladesh Introduces Country-Wide Lockdown, as Factories Already Face 'Indefinite Shutdown', Sourcing Journal, 25 March 2020.

EU Agency for Fundamental Rights (FRA), 'Stop labour exploitation and protect workers from COVID-19', News Item 13 July 2020, available at www. fra.europe.eu.

Fair Labour Association, COVID-19 PANDEMIC GUIDANCE DOCUMENT: Workplace-Level Preparations and Safeguards, available at www.fairlabor.org. 
García-Muñoz Alhambra, M.A., Haar, B.P. ter, and Kun, A., 'Soft on the Inside, Hard on the Outside: An Analysis of the Legal Nature of New Forms of International Labour Law', International Journal of Comparative Labour Law and Industrial Relations, (2011) 27(4), 337-363.

García-Muñoz Alhambra, M.A., Haar, B.P. ter, and Kun, A., 'Harnessing Public Institutions for Labour Law Enforcement. Embedding a Transnational Labour Inspectorate within the ILO', International Organizations Law Review 17(2020) 233-260.

Haar, B.P. ter, 'Love, Flirt or Repel: Hybrid global governance of the ILO core labour standards', European Journal of Social Law 2(2013) 68-102.

Haar, B.P. ter, and Kun, A. 'The CSR-policy of the EU in a global context with specific regard to its uneven regional implementation across Europe', in J.R. Bellace and B.P. ter Haar (eds.), Research Handbook on Labour, Business and Human Rights Law (Cheltenham, Edward Elgar) 2019.

Haar, B.P. ter, Menegatti, E., Senatory, I. and Sychenko, E. (eds.) 'COVID-19 and Labour Law. A Global Review', special issue of the Italian Labour Law e-Journal (2020), https://illej.unibo.it/.

Hätönen, J. and Eriksson, T. '30+ years of research and practice of outsourcing-Exploring the past and anticipating the future', Journal of International Management 15 (2009) 142-155.

Heeringa, D., 'Gaan we in plaats van 'Made in China' vaker 'Made in the Netherlands' zien?', Nieuwsuur (TV programme) 29 May 2020.

Hepple, B. Labour Laws and Global Trade (Oxford: Hart Publishing) 2005.

Hoeks, V. 'Corona onder controle? De Chinezen willen door! Hoe China werkt volgens 'het nieuwe normaal' en hoe Europa daarop in kan springen', available at: https://leidenasiacentre.nl/corona-onder-controle-de-chinezenwillen-door-dutch/.

Hossain, A. 'Coronavirus: Two million Bangladesh jobs 'at risk' as clothes orders dry up', BBC Bengali 29 April 2020.

Hughes Jennett, J., Hamzi, L., and Mashru, R., 'Corporate Human Rights Due Diligence in times of COVID-19', EJIL:Talk! Blog of the European Journal of International Law, 30 July 2020.

IOE and ILO-ACT/EMP, A global survey of employer and business membership organizations: Inside impacts and responses to COVID-19, published by the International Labour Office, 29 June 2020.

ILO Centenary Declaration for the Future of Work, adopted by the Conference at its One Hundred And Eighth Session, Geneva, 21 June 2019, available at www.ilo.org.

ILO, 'COVID-19 impact onchild labour and forced labour:The response of the IPEC+ Flagship Programme', available at www.ilo.org/ipec-plus.

ILO Monitor: COVID-19 and the world of work, available at www.ilo.org.

ILO News, 'COVID-19 cruelly highlights inequalities and threatens to deepen them', 30 March 2020. 
ILO Rules of the Game An introduction to the standards-related work of the International Labour Organization (Centenary edition 2019), available at www. ilo.org.

Ivanov, D. 'Predicting the impacts of epidemic outbreaks on global supply chains: A simulation-based analysis on the coronavirus outbreak (COVID-19/ SARS-CoV-2) case', Transportation Research Part E 136 (March 2020) 101922.

Ivanov, D. and Das, A. 'Coronavirus (COVID-19/SARS-CoV-2) and supply chain resilience: a research note', Int. J. Integrated Supply Management, 13(1) 2020, 90-102.

Jonge, A. de, Transnational Corporations and International Law. Accountability in the Global Business Environment, (Cheltenham; Edward Elgar) 2011.

Koç, A., 'Volledige Steun van de raad voor het terughalen van productie uit lagelonenlanden', Nieuwsbrief CDA Enschede, 15 November 2013.

Langille, B.A. 'Core Labour Rights - The True Story (Reply to Alston)', 16(3) European Journal of International Law (2005), 409-437.

Locke, R. The Promise and Limits of Private Power (Cambridge; CUP) 2013.

Maupain, F., 'Revitalization not Retreat. The Real Potential of the 1998 ILO Declaration for the Universal Protection of Workers' Rights', 16(3) European Journal of International Rights (2005), 439-465.

Meenakshi, S. 'Covid-19: It's time to show what responsible means', Fair wear Foundation (Stories), 28 April 2020, available at: www.fairwear.org/stories/ covid-19-its-time-to-show-what-responsible-means.

Minister Bruno Le Maire's speech European industrial independence of 2 April 2020, available at: www.gouvernement.fr/en/european-industrial-inde pendence.

Montero, M.J., Araque, R.A., Rey, J.M., 'Occupational health and safety in the framework of corporate social responsibility', Safety Science 27 (2009) 1440-1445.

Neuteboom, N. and Golec, P. 'Consumers in the coronavirus era', ABN AMRO 21 April 2020.

OECD, 'COVID-19 and Responsible Business Conduct', OECD Policy Responses to Coronavirus (COVID-19), 16 April 2020.

OECD, 'COVID-19 and Global Value Chains: Policy Options to Build More Resilient Production Networks', OECD Policy Responses to Coronavirus (COVID-19), 3 June 2020.

Oxford Business Group, 'The impact of Covid-19 on global supply chains', COVID 19 Economic Impact Assessment 24 April 2020.

Pamuk, H. and Shahal, A., 'Trump administration pushing to rip global supply chains from China: officials', Reuters (Business) 4 May 2020.

Papadakis, K., (ed.), Shaping Global Industrial Relations. The Impact of International Framework Agreements. (New York, Palgrave MacMillan) 2011.

Patel, J. and Child, S., 'Rise in forced labour expected amid the Covid-19 economic crisis', MailEGuardian, 20 June 2020. 
Pisch, F. 'Managing Global Production: Theory and Evidence from Just-in-Time Supply Chains', CEP Discussion Paper No 1689 April 2020.

Price, Waterhouse, Coopers (PWC), with information and guidelines on global level, available at www.pwc.com.

Ranney, M.L., Griffeth, V. and Jha, A.K., 'Critical Supply Shortages - The Need for Ventilators and Personal Protective Equipment during the Covid-19 Pandemic', The New England Journal of Medicine 30 April 2020.

Responsible Business Alliance, Responsible Business Conduct During The Covid-19 Crisis, available at www.responsiblebusiness.org

Ryder, G., "Social protection a vital part of the pandemic response" (available at www.ilo.org - COVID-19 and social protection).

Sarkis, J., Cohen, M.J., Dewick, P., Schröder, P., 'A brave new world: Lessons from the COVID-19 pandemic for transitioning to sustainable supply and production', Elsevier Public Health Emergency Collection, 17 April 2020 (doi: https://doi.org/10.1016/j.resconrec.2020.104894).

Schnirring, L., 'Global COVID-19 total nears 14 million amid appeal for nations in crisis', CIDRAP News 17 July 2020.

Seric, A., Görg, H., Mösle, S., and Windisch, M. 'Managing COVID-19: How the pandemic disrupts global value chains', Opinion on UNIDO's Industrial Analytics Platform April 2020.

SOMO, Should I stay or should I go?, Discussion Paper (April 2016), available at www.somo.nl.

SOMO, ECCHR and PAX, Responsible disengagement in the time of corona, Position paper, April 2020.

Trebilcock, A., 'Due Diligence on labour issues - Opportunities and limits of the UN Guiding Principles on Business and Human Rights', in A. Blackett and A. Trebilcock (eds), Research Handbook on Transnational Labour Law (Cheltenham: Edward Elgar) 2015, 93-107.

United Nations, UN leads bid to help 135 countries get vital COVID-19 medical kit, amid severe global shortages 28 April 2020.

UN Development Programme, 'Human Rights Due Diligence and COVID-19: Rapid Self-Assessment for Business', available at www.undp.org.

Valinsky, J. 'Business is booming for these 14 companies during the coronavirus pandemic', CNN Business 7 May 2020.

White, E, Jung-a, S., Miller, J., and Cambell, P. 'EU and US carmakers warn 'weeks away' from China parts shortage', Financial Times 4 February 2020. 


\section{Responsabilité sociale des entreprises pendant la pandémie de COVID-19 Résumé}

La pandémie de COVID-19 a provoqué diverses perturbations dans les chaînes de production dans des entreprises multinationales, parmi lesquelles la baisse des ventes, conséquence courante des mesures de confinement (lockdown measures). Toutefois, il y en a d'autres, comme des annulations inattendues des promesses d'achat, la suspension du paiement pour les produits déjà achetés et des produits tout prêts et, par conséquent, la rupture des contrats de travail. Les organisations internationales et non gouvernementales ont sollicité les entreprises multinationales d'adhérer au principe de la responsabilité sociale des entreprises (RSE) et de respecter les contrats. Le but de l'article est d'analyser dans quelle mesure cet appel moral est aussi une sorte de recours juridique issu des normes internationales régissant la RSE. Après avoir présenté et évalué l'importance des principaux problèmes liés au fonctionnement du droit du travail à l'époque de la pandémie de COVID-19, les problèmes ainsi identifiés ont été analysés séparément et en détail. Les conclusions indiquent que les entreprises multinationales sont en effet obligées d'assumer leurs responsabilités non seulement moralement, mais aussi en application des normes internationales (quasi) juridiques de la RSE.

Mots-clés : RSE, COVID-19, Principes directeurs des Nations Unies relatifs aux entreprises et aux droits de l'homme, chaînes de production mondiales, entreprises multinationales, OIT (Organisation internationale du travail), Responsible Business Conduct (conduite responsable des entreprises)

\section{Odpowiedzialność społeczna przedsiębiorstw w czasie pandemii COVID-19}

Streszczenie

Pandemia COVID-19 spowodowała różnego rodzaju zaburzenia w łańcuchach produkcyjnych przedsiębiorstw wielonarodowych. Jednym z nich jest spadek sprzedaży jako powszechna konsekwencja obostrzeń związanych z zakazem przemieszczania się (lockdown measures), których skutkiem są nieoczekiwane rezygnacje z transakcji zakupu towarów, nierealizowanie płatności za towary już zakupione i za gotowe produkty i - w dalszej konsekwencji - zrywanie umów o zatrudnienie. Organizacje międzynarodowe i pozarządowe zaapelowały do przedsiębiorstw wielonarodowych o przestrzeganie zasady społecznej odpowiedzialności biznesu (CSR) i respektowanie umów. Celem artykułu jest analiza stopnia, w jakim ten moralny apel jest jednocześnie rodzajem prawnego wezwania płynącego $\mathrm{z}$ międzynarodowych norm regulujących CSR. Po przedstawieniu i ocenie doniosłości głównych problemów związanych $\mathrm{z}$ funkcjonowaniem prawa pracy $\mathrm{w}$ dobie pandemii COVID-19, osobnej analizie poddane zostały rozpoznane $\mathrm{w}$ ten sposób zagadnienia. We wnioskach wskazuje się, że przedsiębiorstwa wielonarodowe rzeczywiście są nie tylko moralnie zobligowane do podjęcia odpowiedzialności, lecz również w oparciu o (quasi-)prawne międzynarodowe normy CSR.

Słowa kluczowe: CSR, COVID-19, Wytyczne ONZ dotyczące biznesu i praw człowieka, globalne łańcuchy produkcyjne, przedsiębiorstwa wielonarodowe, ILO (Międzynarodowa Organizacja Pracy), Responsible Business Conduct (Odpowiedzialne postępowanie $\mathrm{w}$ biznesie) 